contains is the following: "The Panel have been impressed by the opinion consistently advanced by the University representatives who have attended the meetings that among their graduates those suited to a research career form but a small proportion of the whole; the remainder, while fully competent to absorb and profit by the scientific and technical curriculum, appear to lack those powers of patient and deep-seated inquiry which characterize the natural research worker and lead him to expose new truths".

Such a conclusion emphasizes the duty of all in industry, research establishments or universities who have the opportunity of discovering real research ability to be vigilant for its occurrence and assiduous in its nurture.

J. Grurig

\section{THE BRITISH COUNCIL ANNUAL REPORT}

$\mathrm{T}$ HE annual report of the British Council for the year ended March 31, 1947, only became available a short time ago. The report itself is preceded by an introductory re-statement of the general aims, duties and organisation of the Council, which indicates concisely but lucidly the place of the Council in explaining British cultural achievements and the background of social life, and also the broad grounds on which a grant-in-aid of about three million pounds a year is justified. Referring to the widespread demand for teaching the English language created by the War, the report records the Council's decision in principle not to engage in the direct teaching of elementary English, but to assist, in conjunction with the ministry of education of the country concerned, in improving the standard of teaching of the English language. Concluding that too much effort had in the past been concentrated on the intelligentsia and on the capital cities of foreign countries, the Council also made every effort during the year to widen its influence through contacts with workers' educational movements and with study groups in smaller towns, and it is planned to provide a number of short-term bursaries to enable trade unionists, artisans and apprentices to visit Great Britain to meet their fellows and study the conditions of work in factories, etc. At the invitation of the Commonwealth authorities, a centre was established in Australia during the year, an experiment which has been an unqualified success.

During the year, 248 new scholarships, including three senior fellowships, were awarded as compared with 307 in 1945-46, and 190 scholarships were extended. In addition, nearly two hundred private students were assisted by the Council to secure places at British universities; and vacation courses for overseas students were held at St. Andrews, Oxford and Queen Mary College, London, the last being a specialized course on high-voltage engineering. Lecture tours organised numbered 97 in 28 countries, as against 70 in 1945-46. Thirty-seven new brochures, revised editions and reprints were issued during the year, the series generally in most demand in Europe being British Life and Thought, Science in Britain and The Arts in Britain; in the Balkans, the Middle East, Africa and South America, Britain Advances and British People are more in demand. The Council's work in the field of copyright has now been transferred to the Central Office of Information, but the year was marked by the founding of Council libraries in many European countries and their consolidation in others. Collaboration with the Information Services of the Foreign Office towards pooling resources in joint libraries, functioning both as special reference centres on current British affairs and as Council libraries, is designed to prevent overlapping. Large exchanges of books took place with the U.S.S.R. through the Lenin Library at Moscow, and universities and other centres of Russian studies in Britain have thus received valuable material. In the Colonies, the Council is concerned mainly with assisting the development of library services generally. Two small exhibitions of scientific and medical books were sent to Norway, and an exhibition, with extensive technical and medical sections, toured widely in Switzerland, while one of scientific and technical books was shown in Brussels, Antwerp, Liège, Ghent and Louvain. Some 1,800 periodicals, covering all branches of the humanities, science, medicine and technology, were made available in 1,168 centres in eighty-five countries, and exchanges totalled 3,476 , involving 791 foreign and 765 British periodicals, including 77 British Commonwealth publications. Indexes and contents lists for the war years of sixty specialist periodicals were microfilmed and 25 copies of the film distributed to Austria, Belgium, China, Czechoslovakia, Denmark, Finland, France, Greece, Netherlands, Hungary, Italy, Norway, Poland and Yugoslavia, while in Europe 67 universities and specialist libraries in 15 countries were supplied with British periodicals by presentation or exchange.

Scientific workers form a large proportion of British Council visitors to Great Britain and of lect. urers sponsored overseas by the Council. In collabora. tion with the Scientific Instrument Manufacturers' Association, under the auspices of the Academy of Engineering Science and the Swedish Association of Technical Physics, an exhibition of scientific instruments was organised in Stockholm in May-June, 1946. Assistance was given to the expedition planning to survey a large freshwater lake in Venezuela, and arrangements have been made for the exchange of biological specimens between Brazil and various museums and laboratories in Britain. Many countries have used the Science Department for effecting ex. changes of material, and the Department has advised on scientific appointments overseas, scientific films and film strips and on the publication of Science in Britain. Production of Science Comment was suspended in September 1946 as it had become partly absorbed in the modified Monthly Science News.

The fourth volume of British Medical Bulletin, produced during the year in Spanish and French editions as well, has been placed on a sales basis in countries where currency and other regulations permit, and free distribution is being reduced to a minimum. Medical periodicals received by the Library from other countries, mainly in exchange for the British Medical Bulletin, now number more than 650, and all important British medical books as well as many foreign ones are now received for review in the Bulletin. The Medical Department also handled an increasing number of inquiries, mainly bibliographical, and supplied many reprints and Photostat copies of articles in response to requests from abroad. Advice was given on questions of technical education and postgraduate training in Britain to 93 overseas studies from thirty countries, ranging over some twenty branches of engineering and science, and advice was also given on numerous agricultural subjects 